УДК 330.46

JEL classification: $C 02, F 1, F 47, Q 17$

\author{
Владімірова О. T. \\ ORCID ID: 0000-0002-8246-1753
}

Іваненко В. I.

доктор техн. наук, професор

ORCID ID: 0000-0003-2132-8518

Національний технічний університет Украӥни „Київський політехнічний інститут імені Ігоря Сікорського”

\title{
МОДЕЛЮВАННЯ ЗОВНІШНЬОЇ ТОРГІВЛІ В АГРАРНОМУ СЕКТОРІ УКРАЇНИ
}

\section{MODELLING OF FOREIGN TRADE IN THE AGRICULTURAL SECTOR OF UKRAINE}

У статті розглянута можливість розв'язання задачі максимізачії прибутку від реалізаиії провідної продукиії рослинного походження на аграрному ринку зернових культур - пшениці, кукурудзи та ячменю з краӥнами СС. 3 подальшим визначенням оптимальної кількості нащіонального споживання, експорту та імпорту. В основі статті лежить модернізація оптимізачійної моделі, щзо була виведена М. Л. Вдовин у роботі «Математичне моделювання в управлінні експортно-імпортними операчіями країн Центральної та Східної Свропи». Точніме ї̈ адаптація під аграрний сектор України. Оптимізувавши аграрний сектор можна отримати підвищення конкурентоспроможності сільськогосподарського виробництва, щзо є надзвичайно важливим, бо ступінь розвитку національної економіки в певній мірі залежить від здатності максимально раціонально використовувати наявні ресурси краӥни та дозволяє отримати більщі переваги при проведенні зовнішньоторговельних операчій, які забезпечують довготермінове економічне зростання начіонального господарства.

Прогноз здійснений на 2018 та 2019 рік з урахуванням тарифних квот, отриманих в рамках Угоди про асочіачію, яка набула сили з січня 2016 року.

Через новизну цих змін в політику дана постановка задачі не є достатньо вивченою i тому є актуальною на сьогоднішній день. Суть - покращення стану торгівлі через те, що зовнішньоекономічна діяльність $\epsilon$ однією з основних форм економічних відносин України з іншими державами. Також здійснено прогнозування середніх иін, які потрібні для розрахунків моделі, на реалізацію иієї продукиії методом Хольта, щзо допоможе порахувати оптимальну кількість сільськогосподарських культур для подальшого їх розподілу між національним споживанням, експортом та імпортом.

Отримана модель є досить гнучкою $і$ ї̈ можливо адаптувати до будь-яких нових змін в зовнішній торгівлі.

Ключові слова: задача максимізації, оптимізація експорту, оптимізація імпорту, зовнішньоекономічна діяльність, моделювання АПК

The article considers the possibility of solving the problem of maximizing the profit from the sale of the leading products of plant origin in the agrarian market of cereals - wheat, corn and barley with EU countries. With the further determination of the optimal amount of national consumption, exports, and imports. At the heart of the article is the modernization of the 
optimization model, which was derived by M. L. Vdovin in the paper "Mathematical modeling in the management of export and import operations in the countries of Central and Eastern Europe". To be precise, its adaptation to the agrarian sector of Ukraine. By optimizing the agrarian sector, it is possible to increase the competitiveness of agricultural production, which is extremely important, because the degree of development of the national economy depends to a certain extent on the ability to use the available resources of the country as efficiently as possible and allows for greater advantages in foreign trade operations that ensure the long-term economic growth of the national economy.

The forecast is for 2018 and 2019, taking into account the tariff quotas received under the Association Agreement, which came into force in January 2016. Due to the novelty of these changes in politics, this statement of the problem is not sufficiently studied and therefore relevant to the present day. The bottom line is the improvement of the state of trade due to the fact that foreign economic activity is one of the main forms of economic relations of Ukraine with other states. Also, the average prices required for calculating the model for the realization of these products by the Holt method have been forecast, which will help to calculate the optimum amount of crops for further distribution between national consumption, export, and import

The resulting model is flexible enough and can be adapted to any new changes in foreign trade.

Keywords: maximization problem, export optimization, import optimization, foreign economic activity, modeling of agroindustrial complex

Вступ. Традиційною та найрозвинутішою формою міжнародних економічних відносин є зовнішня торгівля. Вона має зв'язок між виробниками різних країн, яка виникає на основі міжнародного поділу праці та відображає їхню взаємну економічну залежність. У сучасних умовах активна участь країни у світовій торгівлі пов'язана 3 отриманням нею значних переваг: торгівля дає змогу ефективніше використовувати наявні в країні ресурси, полегшує доступ до світових досягнень науки та техніки, зменшує затрати на структурну трансформацію, а також дає змогу краще задовольняти потреби населення.

Загалом, питання моделювання зовнішньої торгівлі розкривалося в роботах багатьох вітчизняних та закордонних вчених-економістів. Серед них Московкін В. М. [4], що використовує матричний метод аналізу, Іваненко І. А. [3], який використовує кореляційно-регресійний аналіз, Ю. В. Василенко [2] досліджував поведінку показників експорту та імпорту при девальвації національної валюти, коли експорт та імпорт описується лінійними функціями. Також П. Пойхьонен та Я. Тінберген [5] вивели традиційне гравітаційне рівняння, що зараз має досить поширене застосування.

Основою моделі, що розглянута в статті стала задача максимізації доходу від реалізації продукції. Ця задача була виведена у роботі М. Л. Вдовин «Математичне моделювання в управлінні експортно-імпортними операціями країн Центральної та Східної Європи» [1]. Але ця задача $є$ універсальною і в цій роботі взято розв'язання цієї задачі на реальних даних 
агарного сектору, а саме продукції рослинництва: пшениці, кукурудзи та ячменю. Бо частка АПК та харчової промисловості в першій половині 2017 році становила 43\% товарного експорту [8]; це більш ніж вдвічі перевищує частку цієї продукції в експорті 2008 року. Це перспективна галузь нашої країни і іï розвиток вкрай важливий для зовнішньоторговельного потенціалу загалом.

32013 року на тлі економічної кризи пов'язаної з погіршенням стосунків між Україною та Росією, відбулась певна переорієнтація зовнішньоторговельних потоків з Росії до ЄС та торгових потоків ЄС з Росії до України, що актуалізувало питання дослідження саме торговельних потоків до/з СС. I зараз спостерігається тенденція до виходу на нові ринки, головним серед яких $\epsilon$ ринок $Є С$. Сукупна частка ринку $\mathrm{CC}$ в обсязі українського експорту товарів зросла з 25,9\% у 2008 р. до 37,1\% у 2016 р.

Слід зазначити, що однією із ключових запорук успішного ведення зовнішньоторговельної політики є визначення оптимальної структури імпорту та експорту, збільшення показників економічного зростання, і це можна зробити за допомогою економіко-математичних моделей.

Постановка завдання. Мета статті полягає у моделюванні оптимальної кількості експорту, імпорту та споживання продукції рослинництва між Україною та ЄС і максимізації доходу від реалізації цієї продукції, 3 урахуванням певних обмежень. Що дасть змогу поліпшити стан торгівлі товарами та дозволить підвищити конкурентоспроможності сільськогосподарського виробництва. I це призведе до покращення становища країни у світі.

Методологія. Теоретичною та методологічною основою досліджень стали праці провідних вітчизняних та зарубіжних вчених-економістів, у яких розглянуто сучасні наукові погляди на економічні проблеми управління зовнішньоторговельною діяльністю, а також праці провідних аналітиків, присвячені проблемам i методології моделювання зовнішньоторговельної діяльності та оптимізації експортно-імпортних операцій, комплексні підходи, що базуються на поєднанні економічного аналізу та методів економікоматематичного моделювання. При вирішенні поставлених завдань використовувались економіко-статистичні та економіко-математичні методи.

Результати дослідження. Оскільки зовнішня торгівля будь-якої країни є сукупністю експортних та імпортних операцій, то головним завданням зовнішньоторговельної політики є насамперед пошук балансу між цими двома товаропотоками.

Розглянемо задачу максимізації доходу від реалізації продукції підприємств країн з трансформаційною економікою. Ця задача була виведена у роботі «Математичне моделювання в управлінні експортно-імпортними операціями країн Центральної та Східної Свропи» [1]. 
Суть - покращення стану торгівлі товарами та послугами, який буде залежати від максимального доходу від реалізації продукції. Нехай в певній країні здійснюється випуск $\mathrm{n}$ видів продукції ( $i=\overline{1, n}, i-$ індекс певного виду продукції). Для випуску цієї продукції використовується $\mathrm{m}$ видів ресурсів ( $k=\overline{1, m}, k-$ індекс певного виду ресурсу). Витрати $\mathrm{k}$-го ресурсу на виробництво і-го виду продукції $a_{k i}$. Вся кількість ресурсів, що витрачається на випуск продукції становить:

$$
S_{k}(k=1, m) .
$$

Використаємо такі позначення:

n - кількість видів продукції;

$i$ - індекс певного виду продукції;

$J$ - кількість країн;

$y_{i j}-$ кількість $i-$ го виду продукції, яка вироблена $j$ - ю країною;

$I_{i}$ - кількість продукції, що $є$ на світовому ринку;

$D_{i}$ - попит на продукцію $i$ - го виду;

$F_{i}-$ функціональна залежність від кількості $i$ - го виду продукції, що потрапляє на світовий ринок - $I_{i}$, та попитом на цю продукцію $D_{i}$;

$\mathrm{m}$ - кількість видів ресурсів;

$k-$ індекс певного виду ресурсу;

$a_{k i}$ - витрати k-го ресурсу на виробництво і-го виду продукції;

$S_{k}-$ кількість ресурсів, що витрачається на випуск продукції;

$\mathrm{Z}$ - дохід від реалізації продукції

Невідомі величини:

$K_{i}$-обсяг експорту продукції

$M_{i}$-обсяг імпорту продукції

$\mathrm{C}_{i}$ - національне споживання $i-$ го вибору продукції

Шукатимемо набір величин $\left(K_{i}, M_{i}, \mathrm{C}_{i}\right)$, який забезпечить максимальний дохід від реалізації продукції Z

Отже, $з$ точки зору торгівлі товарами та послугами основна мета для торгівлі - максимальний дохід від реалізації продукції, який можна визначити наступним чином:

$$
Z=\sum_{i=1}^{n} q_{i} \times P_{i}
$$

де Z - дохід від реалізації продукції;

$q_{i}$ - кількість $i-$ го виду продукції;

$P_{i}$ - ціна $i$ - го виду продукції; 
Причому ціну реалізації $i$ - го виду продукції $P_{i}$, можна визначити як певну функціональну залежність від кількості $i$-го виду продукції, що потрапляє на світовий ринок - $I_{i}$, та попитом на цю продукцію $D_{i}$

Це можна записати так:

$$
P_{i}=F_{i}\left(I_{i}, D_{i}\right)
$$

Щодо кількості $i$-го виду продукції, що $\epsilon$ на світовому ринку (вироблена сукупністю країн світу), можна зазначити, що вона складається 3 продукції, що вироблена підприємствами даної країни та продукції, що вироблена підприємствами інших країн.

Кількість продукції на світовому ринку:

де J - кількість країн;

$$
I_{i}=q_{i}+\sum_{j=1}^{J} y_{i j}
$$

$y_{i j}$-кількість $i-$ го виду продукції, яка вироблена підприємствами $j$ - ої країни;

$I_{i}$ - кількість продукції, що $є$ на світовому ринку;

$q_{i}$ - кількість $i-$ го виду продукції, що вироблена підприємствами нашої країни.

Крім цього варто зазначити, що вся продукція $i$-го виду, що споживається в нашій країні складається 3 продукції, що ввезена до нас (імпорту) та продукції, що вироблена підприємствами нашої країни 3 врахуванням продукції даного виду, що була експортована країною.

Отже, національне споживання можна визначити таким чином:

де $K_{i}$ - обсяг експорту продукції;

$$
C_{i}=M_{i}+q_{i}-K_{i}
$$

$M_{i}$-обсяг імпорту продукції;

$\mathrm{C}_{i}$ - національне споживання $i$ - го вибору продукції;

Звідси можна знайти $q_{i}$ :

$q_{i}=C_{i}+K_{i}-M_{i}$

де $q_{i}$ - кількість $i$ - го виду продукції, що вироблена нашою країною.

Економічно-математична модель задачі виглядатиме таким чином:

$$
\begin{gathered}
Z=\sum_{i=1}^{n}\left(C_{i}+K_{i}-M_{i}\right) \times F_{i}\left(\left(C_{i}+K_{i}-M_{i}\right)+\sum_{j=1}^{J} y_{i j}\right. \\
\sum_{i=1}^{n} a_{k i} \times\left(C_{i}+K_{i}-M_{i}\right) \leq S_{k}, k=\overline{1, m} \\
K_{i} \geq 0, M_{i} \geq 0, C_{i} \geq 0
\end{gathered}
$$

Цільова функція (7) показує досягнення максимального доходу від реалізації продукції підприємств від торгівлі товарами та послугами.

Перше обмеження (8) показує, що кількість спожитих ресурсів визначається нормою витрат та обсягом виробленої продукції 
Друге обмеження (9) показує, що необхідною умовою є досягнення позитивного сальдо зовнішньоторговельного балансу.

Оскільки зовнішня торгівля $\epsilon$ динамічним явищем, то часто спостерігаємо ситуацію, коли імпорт перевищує за обсягами експорт, що, своєю чергою, формує зовнішню заборгованість країни та зменшує добробут громадян, котрі змушені сплачувати додаткові збори для оплати відсотків такої заборгованості.

Також всі невідомі змінні повинні бути невід’ємними (10).

Так як зовнішньоекономічні зв'язки займають значне місце в системі агропромислового комплексу економічної діяльності України розглянемо цю моделі на прикладі продукції АПК.

На тлі спадаючого обсягу загальної експортної виручки зростає частка сільськогосподарської продукції. За перше півріччя 2017 року, частка сільськогосподарської продукції у структурі експорту України складає 42,2\%. Проте варто зазначити, що основу аграрного експорту все ще становить експорт сировини, а саме продукція рослинного походження - пшениця, кукурудза та ячмінь.

В попередні роки не були досконалими механізми регулювання експортно-імпортних операцій, що має свій влив на експортний агропромисловий потенціал України. Пошук способів підвищення ефективності зовнішньоекономічної діяльності в АПК, визначення перспективних сфер розвитку зовнішньої торгівлі, удосконалення механізмів регулювання зовнішньоекономічної діяльності АПК за останні роки набули особливої актуальності.

Україна має достатній експортний потенціал в агропромисловому секторі, але не може його реалізувати в повному обсязі. В Україні $\epsilon$ передумови для закріплення позицій на міжнародних ринках $\mathrm{i}$ створення конкурентоздатної економіки. Проблема покращення експортного потенціалу України на сучасному етапі $є$ дуже актуальною, оскільки на даний момент структура експорту далека від оптимальної.

Отже, спробуємо дослідити цю модель та взяти продукцію рослинництва аграрного сектору України.

У Міністерстві аграрної політики та продовольства заявили, що за попередніми статистичними даними у 2016 році виробництво зернових та зернобобових культур у заліковій вазі склало 66 млн тонн (в 2,7 рази вище порівняно із 2000 роком). Щодо культур, то, зокрема, зібрано: пшениці - 26,0 млн тонн; кукурудзи на зерно - майже 28,0 млн тонн; ячменю - 9,4 млн тонн [6].

Значне зростання обсягів виробництва протягом 2016-2017 років відбулося за рахунок інтенсифікації технологій вирощування, що вплинуло на підвищення урожайності. 
Замість першого обмеження (8) візьмемо обмеження що продуктивність землі помножену на кількість зібраної продукції повинно бути менше ніж відведена площа під посів цієї культури.

$$
\begin{gathered}
\alpha_{i} \times\left(C_{i}+K_{i}-M_{i}\right) \leq S_{i} \\
\sum_{i=1}^{n} S_{i} \leq S_{\text {заг. }}
\end{gathered}
$$

де $\alpha_{i}$-продуктивність землі для і-го виду продукції,

$S_{i}$ - посіяна площа $i-$ тим видом продукції

$S_{\text {заг. }}$ - посівна площа

В останні роки посівна площа в Україні не змінювалася і становить 26,8 млн га [6].

Посівна площа для обраних видів продукції становить [6]:

- для пшениці - 6368,3 тис. га;

- для кукурудзи на зерно - 4522,4 тис. га;

- для ячменю - 2859,2 тис. га.

31 січня 2016 року в Україні офіційно почала діяти поглиблена та всеосяжна зона вільної торгівлі (ПВЗВТ) з СС.

Угода впливає на експорт, на імпорт, на прямі іноземні інвестиції та інші канали надходження капіталу. Вплив на економічні відносини всередині країни стосується бізнес-клімату, конкурентоспроможності, продуктивності тощо.

У додатках до Угоди повністю описано тарифне регулювання торгівлі між Україною та ЄС. Система регулювання включає: мита, тарифні квоти, вхідну ціну.

Мито стягується митницею ЄС при надходженні товарів на їх ринок. Для більшості сільськогосподарської продукції мито на імпорт з України до ЄС було скасоване 31 січня 2016 року в рамках Угоди про асоціацію. Для кожного продукту вказано базову ставку ввізного мита та перехідний період, під яким розуміють проміжок часу, впродовж якого ставка мита прямо пропорційною буде зменшена або повністю скасована.

Від осені 2017 року запроваджені тарифні квоти на постачання цієї продукції в країни СС.

Вони становлять для обраної продукції:

- для пшениці -950000 - 1000000 тонн/рік, при перевищенні 95 $€ / \mathrm{T}$;

- для кукурудзи - 400000 - 650000 тонн/рік, мито $94 € / \mathrm{T}$;

- для ячменю -250000 - 350000 тонн/рік, мито - $93 € /$.

Отже, додаємо обмеження до моделі:

$$
K_{i} \leq \mathrm{T}_{i}
$$

де $\mathrm{T}_{i}$ - тарифна квота $i$ - го виду продукціі; 
$K_{i}$ - обсяг експорту продукції.

Отже, економіко-математична модель:

$$
\begin{gathered}
Z=\sum_{i=1}^{n}\left(C_{i}+K_{i}-M_{i}\right) \times P_{i} \rightarrow \max \\
\alpha_{i} \times\left(C_{i}+K_{i}-M_{i}\right) \leq S_{i} \\
\sum_{i=1}^{n} S_{i} \leq S_{\text {заг. }} \\
K_{i} \leq \mathrm{T}_{i} \\
K_{i}-M_{i} \geq 0, i=\overline{1, n} \\
K_{i} \geq 0, M_{i} \geq 0, C_{i} \geq 0
\end{gathered}
$$

Де $P_{i}-$ середня прогнозна ціна реалізації $i-$ го виду продукції.

Для вирішення задачі було використано програми Excel та Mathcad.

Спочатку, зробимо прогноз для середньої ціни реалізації обраної продукції. Для прогнозування ціни реалізації основної продукції рослинництва візьмемо дані за 2010-2017 (для 2017 взята середня ціна за 11 місяців) та проаналізуємо наявність тренду в динамічному ряді методом Фостера-Стьюарта (табл. 1).

Даний метод надає більш надійні результати, ніж інші подібні йому методи. Цей метод дозволяє виявити тренд у значенні дисперсії рівнів, що $є$ важливим для прогнозного аналізу.

Таблиця 1- Динаміка середніх цін реалізації сільськогосподарської продукції за основними напрямами рослинництва

\begin{tabular}{|c|c|c|c|}
\hline & Пшениця & Кукурудза & Ячмінь \\
\hline 2010 & 1052,7 & 1158,7 & 1091,8 \\
\hline 2011 & 1401,8 & 1314,7 & 1638,6 \\
\hline 2012 & 1473,4 & 1447,3 & 1798,4 \\
\hline 2013 & 1377,8 & 1163,7 & 1669,1 \\
\hline 2014 & 1680,5 & 1712 & 1786,9 \\
\hline 2015 & 2527,7 & 2682,6 & 2841,8 \\
\hline 2016 & 3006,7 & 3311,4 & 2981 \\
\hline 2017 & 3829,4 & 3563,8 & 3591,8 \\
\hline
\end{tabular}

Після аналізу цін виявлено, що ряд має тренд як по середньому так і по дисперсії. Також бачимо, що часовий ряд монотонно зростає.

Графіки середніх цін наведено на рисунку. 


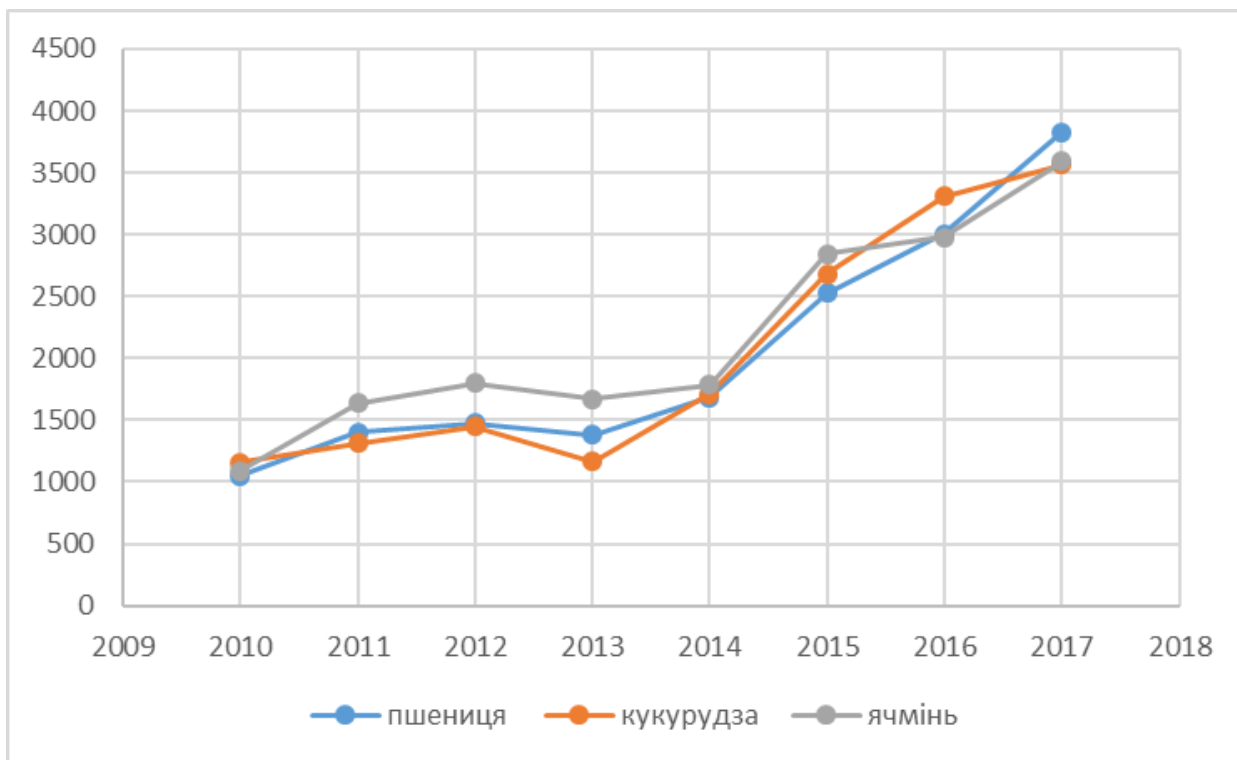

Рисунок - Динаміка середньої ціни реалізації для основної продукції рослинництва

Для подальшого прогнозування потрібно визначити метод, яким будемо прогнозувати дані. Оскільки, в нас невелика вибірка зробимо вибір в користь двопараметричного методу Хольта (20-22). 2).

Отже, розрахуємо прогнозні значення ціни для 2018 та 2019 року (табл.

Таблиця 2 - Прогнозні значення ціни

\begin{tabular}{|c|c|c|}
\hline \multirow{2}{*}{} & \multicolumn{2}{|c|}{ Метод Хольта } \\
\cline { 2 - 3 } & 2018 & 2019 \\
\hline Пшениця & 3906 & 4115,76 \\
\hline Кукурудза & 3756,3 & 3869,2 \\
\hline Ячмінь & 3101 & 3232,9 \\
\hline
\end{tabular}

Коефіцієнт продуктивності землі становить (табл. 3):

Таблиця 3 - Коефіцієнт продуктивності землі

\begin{tabular}{|c|c|c|}
\hline & 2018 & 2019 \\
\hline Пшениця & 0,2196 & 0,2099 \\
\hline Кукурудза & 0,1374 & 0,1312 \\
\hline Ячмінь & 0,2524 & 0,2295 \\
\hline
\end{tabular}

Посівна площа за прогнозними даними становитиме (табл. 4): 
Таблиця 4 - Посівна площа основними сільськогосподарськими культурами

\begin{tabular}{|c|c|c|}
\hline & 2018 & 2019 \\
\hline Пшениця & 6551,3 & 6581,2 \\
\hline Кукурудза & 4175,6 & 4116,7 \\
\hline Ячмінь & 2543,9 & 2420,4 \\
\hline
\end{tabular}
(табл. 5).

Отже, підставивши вихідні данні у модель (14-19) отримали результат

Таблиця 5 - Оптимальна кількість сільськогосподарських культур

\begin{tabular}{|c|c|c|c|c|c|c|}
\hline & \multicolumn{2}{|c|}{ Пшениця } & \multicolumn{2}{c|}{ Кукурудза } & \multicolumn{2}{c|}{ Ячмінь } \\
\hline & 2018 & 2019 & 2018 & 2019 & 2018 & 2019 \\
\hline Експорт & 1530000 & 1620000 & 2100000 & 2145000 & 439400 & 449400 \\
\hline Імпорт & 1000 & 1000 & 2000 & 2000 & 3000 & 3000 \\
\hline Споживання & 1216000 & 1288000 & 123600 & 109200 & 40430 & 56010 \\
\hline
\end{tabular}

I отриманий прибуток (табл. 6):

Таблиця 6 - Прибуток від реалізації сільськогосподарських культур

\begin{tabular}{|c|c|c|c|c|c|}
\hline \multicolumn{2}{|c|}{ Пшениця } & \multicolumn{2}{c|}{ Кукурудза } & \multicolumn{2}{c|}{ Ячмінь } \\
\hline 2018 & 2019 & 2018 & 2019 & 2018 & 2019 \\
\hline 1230390000 & 1370548080 & 7431463920 & 7884655760 & 1246508970 & 1281489231 \\
\hline
\end{tabular}

Висновки. Отримані данні показують оптимальні обсяги експорту, імпорту та національного споживання трьох видів продукції: пшениці, кукурудзи і зерна. Також обрахований приблизний прибуток від реалізації цієї продукції. Звідси слідує, що максимізація доходу від реалізації продукції дає змогу поліпшити стан торгівлі товарами та оптимізувавши аграрний сектор можна отримати підвищення конкурентоспроможності сільськогосподарського виробництва. Що призведе до покращення становища країни у світі та дасть змогу задовольнити потреби внутрішнього ринку та забезпечити провідні позиції у світі шляхом стабільного експорту сільськогосподарської продукції.

Сільське господарство й аграрні підприємства працюють в умовах ризику і невизначеності через істотний вплив природних факторів. Саме під дією цих факторів можуть безпосередньо змінюватися попит і пропозиція, встановлюватися нова рівновага, а отже, і нова ціна. Тому в подальших дослідженнях потрібно додати ці умови. 
Також завжди потрібно розробляти виважену зовнішньоторговельну політику, і вміло поєднувати політику вільної торгівлі та протекціонізм особливо під час поступової переорієнтації торговельних потоків на СС.

В подальшому дослідженні можна дослідити моделі зовнішньої торгівлі, що пристосовані саме до аграрного сектору.

\section{Література:}

1. Вдовин, М. Л. Математичне моделювання в управлінні експортно-імпортними операціями країн Центральної та Східної Свропи [Текст] : дис... канд. екон. наук: 08.03 .02 / Вдовин Мар'яна Любомирівна ; Львівський національний ун-т ім. Івана Франка. - Л., 2005. - 223 арк.: рис., табл.

2. Зовнішня торгівля України: чинники, моделі, тенденції / Ю.В.Василенко, Д.Ю.Василенко. - К. : Б. в., 2007. - 345 с. : іл., табл.

3. Іваненко I. А. Аналіз впливу зовнішньої торгівлі з країнами СНД на ВВП України / I. А. Іваненко. // Вісник Маріуполь. держ. ун-ту. - 2001. - С. 166-174.

4. Московкин В. М. Матричный анализ товарно-страновой структуры внешней торговли: на примере Украины и стран ЕС / В. М. Московкин. // Актуальні проблеми економіки. - 2007. - С. 26-36.

5. Новикова М. В. Формування та тестування гравітаційної моделі зовнішньої торгівлі товарами України з країнами ЄС [Електронний ресурс] / М. В. Новикова, Н. Ю. Ткачук. 2011. - Режим доступу до ресурсу: http://jrnl.nau.edu.ua/index.php/PPEI/article/download/282/271.

6. Офіційний сайт Державного комітету статистики України

[Електронний ресурс] : [Веб-сайт]. - Електронні дані. - Режим доступу: http://www.ukrstat.gov.ua.

7. Україна продає світові харчі, а варто додати - технології [Електронний ресурс] - Режим доступу: https://www.ukrinform.ua/rubric-economy/2385935ukraina-prodae-svitovi-harci-a-varto-dodati-tehnologii.html 